Nenad Lemajić

Univerzitet u Novom Sadu

Filozofski fakultet

Odsek za istoriju

nenadlemajic@yahoo.com
Originalan naučni rad

primljeno: 30 . jun 2014

prihvaćeno: 1. oktobar 2014

\title{
RANI KONTAKTI SRBA I HABZBURGOVACA (DO MOHAČKE BITKE)*
}

Sažetak: Kontakti Srba i Habzburgovaca su otpočeli sredinom XV veka. U tom trenutku Habzburgovci su u liku Alberta Austrijskog prvi put seli na presto a Srbi su se borili za opstanak svoje srednjovekovne države. U kasnijem periodu karakter tih kontakata je bio drukčiji. Pojedinačni predstavnici Srba, feudalci prebegli na tlo Ugarske i nove vođe ratničkih družina povezivali su se sa Habzburgovcima nudeći im svoje vojničke usluge. Definitivan prelom nastaće u periodu posle Mohačke bitke kada se Habzburgovac Ferdinand I učvrstio na ugarskom prestolu. Time će otpočeti nov period veoma intenzivnih kontakata Srba sa Habzburgovcima koji će se najvećim delom odvijati na teritoriji razdrobljenog ugarskog kraljevstva koje se borilo za svoj opstanak.

Ključne reči: Srbi, Habzburgovci, Ugarska, Srbi u Ugarskoj.

Srbi i Habzburgovci su se prvi put susreli u ravnicama Panonske nizije. To je oblast u koju su i jedni i drugi došli. Beskrajna ravnica sasvim u suprotnosti sa geografijom predela odakle su poticali. U vreme kada su u nju stigli, bila je to već vekovima zemlja krune Svetog Stefana.

Habzburgovci potiču sa teritorije sadašnje Švajcarske, iz oblasti današnjeg kantona Argau, šumovitog predela gde su u XI veku izgradili utvrđenje po kome će porodica početi da se naziva od vremena Otona II. Kasnije su premestili centar svojih poseda iz tadašnje Švapske u Austriju i Štajersku. Bilo je to u vreme vladavine Rudolfa, prvog Habzburgovca koji je među njima nosio titulu kralja Rimsko-nemačke države. Narednih šest stotina godina te oblasti će biti jezgro Habzburške monarhije. ${ }^{1}$

\footnotetext{
* Текст је настао као фазни резултат рада на пројекту Војвођански простор у контексту европске историје (број 177002) Министарства просвете, науке и технолошког развоја Републике Србије.

${ }^{1} \mathrm{O}$ istoriji Habzburgovaca u srednjem veku i periodu do početka Velikog bečkog rata 1683. postoji značajna literatura, navodimo najznačajnije radove: Andrew Wheatcroft, The Habsburgs; Embodying Empire, London 1996, prvo izdanje: Viking 1995; Dorothy Gies McGuigan, Familie Habsburg 1273-1918, Wien-München 2011; Michael Erbe, Die Habsburger 1493-1918. Eine Dynastie im Reich und in Europa, Stuttgart 2000; Karl Friedrich Krieger, Die Habsburger im Mittelalter: von Rudolf I. bis Friedrich III, Stuttgart 1994; Jean Bérenger, A History of the Habsburg Empire 1273-1700, London -New York, i na francuskom jeziku: Jean Bérenger, Histoire de l empire des Hasbourg, 1273-1918, Fayard, Sep 5, 1990; Robert A. Kann, A History of the Habsburg Empire, 1526-1918, University of California Press, November 1980. i starije izdanje pod istim nazivom 1974;
} 
Po nekim nedovoljno pouzdanim genealogijama, prvi poznati predak porodice Habzburg bio je Guntram Bogati. ${ }^{2}$ On je navodno bio deda prvog pouzdanog predstavnika dinastije Radbota od Klettgaua (c. 985 - 1045). Radbot je bio grof okruga Kletgau. Izgradio je posle 1020. godine zamak Habzburg na reci Aar, pritoci Gornje Rajne. Radbotov unuk Oton II je prvi uzeo ime zamka kao ime porodice stavivši uz svoju titulu „von Habsburg“. Nekoliko narednih generacija porodica se neće izdvajati od sličnih feudalnih porodica današnje Švajcarske. Pravi uspon Habzburgovaca počeće posle interegnuma i propasti dinastije Hoenštaufovaca kada je 1273. godine Rudolf I (12181291) izabran za kralja. Posle nekoliko godina došao je do poseda Austrije, Štajerske i Karantanije koje je definitivno preoteo od češkog kralja Otokara II posle bitke na Moravskom polju (Dürnkrut) 1278. godine. Austrija i Štajerska su tako postale baštinske zemlje porodice, čime će biti stvoreni uslovi za njen dalji uspon.

Tokom narednog stoleća, sve do 1438. godine, Habzburgovci će se smenjivati na prestolu rimsko-nemačkih vladara sa dinastijama Luksemburg i Vitelsbah. Od dolaska Alberta na presto 1438. Habzburgovci su neprestano nosili titulu nemačkih kraljeva odnosno svetih rimskih careva (od krunisanja Fridriha III 1452. godine) sve do XIX veka.

Srbi su se kao srednjovekovni narod formirali na Balkanskom poluostrvu u oblasti današnjeg zapadnog Balkana, južno od reke Save a zapadno od rečne komunikacije Morava-Vardar izolovanoj od svih bitnih ekonomskih i kulturnih komunikacija poluostrva. Srbi su se na ove prostore doselili u vreme velikih seoba, najverovatnije u VII veku, kao deo velike praslovenske zajednice. Talas seoba odveo je deo Srba, kao i brojna druga slovenska plemena, daleko ka jugu u oblasti koje su tada pripadale Istočnom rimskom carstvu. Prvobitna istorija Srba na Balkanu gotovo je potpuno nepoznata. Izvesno je da su se prepoznavali po jeziku, elementima materijalne kulture i opšteslovenskoj paganskoj religiji. Među njima se sačuvala legenda o doseljenju iz stare domovine sa severa koju su zabeležili Vizantinci u izvorima iz X veka. Prvi elementi

Paula Sutter Fichtner, Terror and Toleration: The Habsburg Empire Confronts Islam, 1526-1850, Reaktion, 2008; Paula Sutter Fichtner, The Habsburg Monarchy 1490-1848: Attributes of Empire, Palgrave, 2003; Paula Sutter Fichtner, Emperor Maximilian II, Yale University Press, 2001; Robert John Weston Evans, The Making of the Habsburg Monarchy, 1550-1700: An Interpretation, Oxford University Press, 1979; Adam Wandruszka, The House of Habsburg: six hundred years of a European dynasty, Greenwood Press, Nov 10, 1975; Victor S. Mamatey, Rise of the Habsburg Empire: 1526-1815, Krieger Pub Co, November 1994. i starije izdanje pod istim naslovom Krieger Publishing Company, 1978, a postoji i prvo izdanje: Rise of the Habsburg empire, 1526-1815, Berkshire studies in history, Holt, Rinehart and Winston, 1971; Terror and Toleration: The Habsburg Empire Confronts Islam, 1526-1850. BY MAUREEN HEALY Reininger, Alice. Wolfgang von Kempelen; Geza Palffy, The Kingdom of Hungary and the Habsburg Monarchy in the Sixteenth Century, New Jersey - New York 2009; Sára János, A Habsburgok és Magyarország 950-1918, Budapest 2000; K. Nehring, Matthias Corvinus, Kaiser Friedrich III und das Reich, München 1975; Barta János, Habsburgokés Magyarország a XVI-XVIII században, Debrecen 1997; Eduard Maria Fürst von Lichnowsky, Geschichte des Hauses Habsburg, Bd. 1, Wien 1836; Geschichte des Hauses Habsburg, Bd. 2, Wien 1837; Geschichte des Hauses Habsburg, Bd. 3, Wien 1838; Geschichte des Hauses Habsburg, Bd. 4, Wien 1839; Geschichte des Hauses Habsburg, Bd. 5, Wien 1841; Geschichte des Hauses Habsburg, Bd. 6, Wien 1842; Geschichte des Hauses Habsburg, Bd. 7, Wien 1843; Geschichte des Hauses Habsburg, Bd. 8, Wien 1844; Rad Edvarda Marije First fon Lihnovskog (Eduarda Maria Fürst von Lichnowskog) danas je zastareo ali još uvek zbog brojnih izvoda izvora i regesta povelja ima naučni značaj.

${ }^{2}$ Martin Kiem (Ed.), Acta Murensia, u: Quellen zur Schweizer Geschichte III, Basel 1883; Charlotte Bretscher und Christian Sieber, Staatsarchiv Aargau (Hrsg.), Acta Murensia. Die Akten des Klosters Muri mit der Genealogie der frühen Habsburger, Basel 2012. 
hristijanizacije potvrđeni su u drugoj polovini IX veka i predstavljali su osnov budućeg specifičnog duhovnog razvoja i srednjovekovnog identiteta. Dva pisma prilagođena slovenskim govorima a stvorena van njihovog područja (glagoljica i ćirilica) imala su izuzetnu ulogu u verskoj i kulturnoj recepciji vrednosti tada već greciziranog Istočnog rimskog carstva. Time je stvorena osnova za kasniji autentični kulturni razvoj. Na prostoru koji su naselili Srbi dugo nisu uspevali da stvore jedinstvenu državu. Dinarski masiv koji se skoro bukvalno izdizao iz Jadranskog mora nije bio pogodan za stvaranje jedinstvenog državnog okvira. Umesto njega nastalo je nekoliko država vezanih za grupe kraških polja kojih su ove planine bile pune. Neka među njima bila su povezana i tokovima planinskih reka. Zato nije čudno što kada prvi put u $\mathrm{X}$ veku istorijski izvori beleže pouzdanu geografiju ovog prostora saznajemo za postojanje nekoliko država: kneževinu Neretljana (od Cetine do Neretve), Zahumljana (od Neretve do zaleđa tada romanskog grada Dubrovnika), Travunjana i Konavljana (od zaleđa Neretve do Boke kotorske), Duklju (u dolinama Zete i Morače te oko Skadarskog jezera i Bojane). Dublje u unutrašnjosti nalazila se „krštena Srbija“ koja se na istok prostirala do grada Rasa a u okviru nje se ocrtavala zemlja Bosna. Dokraja XII veka kao posledica gotovo neprekinutog kulturnog i političkog uticaja Vizantije srpske zemlje će osim u svom najzapadnijem delu kao i njihovi istočni susedi Bugari akumulirati osnovni nivo hrišćanstva u istočnom obliku lagano unoseći i specifične slovenske elemente. Ovi slovenski jezičko-duhovni elementi naročito su se širili iz hrišćanskih centara bugarske države (velikog Preslava a mnogo više Ohrida). Sledeći veliki korak u definisanju duhovnog lika Srba učinjen je krajem XII i u prvim decenijama XIII veka u vreme učvršćivanja najznačajnije srpske srednjovekovne dinastije Nemanjića. Oni ne samo što su do sredine XIV veka stvorili veliku i u jednom momentu najsnažniju državu na Balkanu već su formiranjem autokefalne crkve (1219) u nezavisnoj državi i prvim domaćim svetiteljskim kultovima razvili posebnu srpsku hrišćansku tradiciju čime su u duhovnom smislu definisali svoj narod za mnogo narednih vekova. Osobene kulturološke crte nastale u ovom razdoblju postaće deo duhovnog habitusa naroda i uz nadograđivanja prenosiće se narednim generacijama. Tako su nastale granice koje su Srbe odvojile ne samo od onih koji su govorili drugim jezicima već i od istojezičnika sa drukčijim verskim tradicijama: katoličkom u Dalmaciji i dalje na zapadu i bogumilskom u dotada već samostalnoj Bosni. ${ }^{3}$

\footnotetext{
${ }^{3}$ O srednjovekovnoj istoriji Srba postoji brojna literatura. Ovde ćemo navesti samo opšta i najznačajnija dela. Prvu naučnu istoriju Srba napisao je češki istoričar Konstantin Jireček. Prva dva njegova rada iz ove oblasti nose nazive Jireček, C., Die Handelsstrassen und Bergwerke von Serbien und Bosnien während des Mittelalters, Prag 1879 (Trgovački putevi i rudnici Srbije i Bosne u srednjem vijeku, Зборник Константина Јиречека I, Београд 1959); i Die Romanen in den Stadten Dalmatiens während des Mittelalters, Denkschriften der Kaiserlichen Akademie der Wissenschaften in Wien, Philosophisch-historische Classe, Band XLVIII, XLIX, Wien 1901, 1903, 1904 (Романи у градовима Далмачије током средњега века, Зборник Константина Јиречека II, Београд 1962). Zaokružena istorija Srba se pojavila na nemačkom jeziku 1911-1918. godine u dve knjige a radovi iz društvene istorije u časopisu Denksschriften der Kaiserlichen Akademie der Wissenschaften in Wien da bi kasnije čitav opus bio objedinjen u srpskom prevodu kao Istorija Srba I i II: Geschichte der Serben, I-II, Gotha 1911-1918 (Историја Срба, књ. І, Политичка историја до 1537. године, Београд 1952, 1978², $1988^{3}$ ). Staat und Gesellschaft im mittelalterlichen Serbien. Studien zur Kulturgeschichte des 13-15 Jahrhunderts, Denksschriften der Kaiserlichen Akademie der Wissenschaften in Wien, Phil. hist. Klasse Bd. 56, 58, 64, Wien 1912-1919 (Историја Срба, књ. II, Културна историја, Београд 1952, 1978, 1988).
} 
Veze Srba sa krunom Svetog Stefana otpočele su u XII veku kada se srpska princeza Jelena udala za ugarskog prestolonaslednika a njen brat Beloš zadobio visoku titulu vojvode a kasnije i bana. Titulu bana Beloš je nosio preko trinaest godina (11441157). ${ }^{4}$ Koju deceniju ranije Srbi i Ugri su pokušavali da se zajedno odupru pritisku komninske Vizantije a ta borba će se odvijati sve dokraja XII veka. ${ }^{5}$ Promene političkih prilika posle sloma dinastije Komnina drukčije su odredile njihove veze pa je ugarski kralj Emerih (1196-1204) u svoju kraljevsku titulu dodao i Srbiju. Bila je to samo puka pretenzija jer u stvarnosti ugarski kraljevi nikada nisu imali vlast nad srpskim zemljama. ${ }^{6}$

Povremeni dodiri dve države pretvorili su se u nešto više krajem XIII veka. U doba vladavine srpskog kralja Uroša I jedan njegov odred je pomagao kralja ugarske Belu IV u ratu koji je ovaj vodio protiv češkog kralja. Četiri godine kasnije srpski kralj boravi na svečanostima prilikom svadbe mlađeg sina ugarskog kralja. Kada je u proleće 1268 . Uroš I napao na Mačvansku banovinu, oblast koju su ugarski vladari osnovali južno od Save, to je samo naizgled bilo iznenađenje. ${ }^{7}$ Mačvanska banovina stvorena je od Margaritinog miraza na teritoriji koja je bila sporna između Ugarske i Vizantije u prethodnom periodu. Oblast je već tada bila neka vrsta apanaže za članove pobočnih grana Arpadovića da bi se se u vreme Bele IV pretvorila u jednu od nekoliko banovina koje su branile južne granice države. Mačvanskom banovinom su uglavnom nastavili da upravljali pobočni srodnici vladarske kuće. Bela IV je tada Mačvansku banovinu dao na upravu svom zetu Rostislavu Mihajloviću i svojoj ćerci Ani. ${ }^{8}$

Pošto su uspešno odbili napad Srba i zarobili kralja Uroša I, Ugri će za gospodara ove oblasti postaviti Dragutina, zeta kralja Stefana V (1270-1272), koji je tokom svoje vladavine držao i Beograd. Interesi Srbije i Ugarske bili su ovde veoma izukrštani. Mada

Sintetičko-udžbenički pregled istorije Srba objavljen je u: Istorija naroda Jugoslavije, I-II, Beograd-ZagrebLjubljana 1953, 1960, a potom u mnogo kvalitetnijem i opširnijem obliku u: Историја српског народа, I-VI, Београд 1980-1993 (prve dve knjige odnose se na istoriju Srba u srednjem veku). Pregled istorije Srba na engleskom jeziku objavljen je u (History of Yugoslavia, New York 1974) = Božić, I. - Ćirković, S. - Ekmečić, M. - Dedijer, V., Istorija Jugoslavije, Beograd 1972. U novijem periodu pojavile su se iz pera jednog od najvećih srpskih istoričara Sime Ćirkovića dve izuzetne sinteze srpske istorije: Срби у средњем веку, Београд 1995 (I Serbi nel medioevo, Milano 1992; La Serbie au moyen age, Pariz 1992; Сербия средние века, Москва 1996) і Срби међу европским народима, Београд 2004 (= Sima M. Ćirković, The Serbs, April 2004, WileyBlackwel) objavljen i u hrvatskoj verziji Srbi među europskim narodim, Zagreb 2008. Za društvenu, ekonomsku i kulturnu istoriju Srba od izuzetne važnosti je Ћирковић, С. - Михаљчић, Р. (ур.), Лексикон српског средњег века, Београд 1999. O prvim kontaktima Srba i Habzburgovaca vid. Ивић, А., Историја Срба у Војводини од најстаријих времена до оснивања потиско-поморишке границе (1703), Нови Сад, 1929, $1997^{2}$.

${ }^{4}$ Јованка Калић, Жупан Белош, Зборник радова Византолошког института, 36, 1997, 63-79 (= Ј. Калић, Европа и Срби, средњи век, Београд 2006).

5 Јованка Калић, Рашки велики жупан Урош II, Зборник радова Византолошког института, 12, 1970; Историја српског народа, књ. 1, 197-211.

${ }^{6}$ Петер Рокаи, Золтан Ђере, Тибор Пал, Александар Касаш, Историја Мађара, Београд 2002, 58-59.

${ }^{7}$ М. Динић, О угарском ропству краља Уроша I, Историјски часопис, 1, 1948, 30-36.

8 O problematici Mačvanske banovine vid. Сима Ћирковић, Земља Мачва и град Мачва, Прилози за књижевност, језик, историју и фолклор, 1-4, 2008, 3-20; Петер Рокаи, О једном наслову Калојана Анђела, Зборник радова Византолошког института, 19, 1980, 167-171; Петер Рокаи, Gyletus dux Sirmii, Зборник Матице српске за историју, 27, 1983, 121-127; Ђура Харди, Господари и банови оностраног Срема и Мачве у ХІІІ веку, Споменица Историјског архива Срем, 8, 2009, 65-80; Szentpétery Emerich, Das Banat von Machow (Macsó), Ungarische Rundschau für historische und soziale Wissenschaften, 4, 1915, 872-883; СимаЋирковић, Црна Гора и проблем српско-угарског граничног подручја, у: Ваљево - постанак и развој градског средишта, Ваљево 1994, 59-77 
nemamo potpuno pouzdane podatke, može se pretpostaviti da je slovensko stanovništvo bilo brojno a uticaj bliske srpske države se pojačavao. Tada već bivši srpski kralj koji je još uvek imao neke posede u Srbiji zasniva sopstvenu oblast formalno i dalje u sastavu Ugarske a suštinski osamostaljenu i povezanu sa srpskim zemljama. ${ }^{9}$ Jedan putopisac je stekao baš takav utisak kada je početkom XIV veka opisivao prilike u ovim predelima. ${ }^{10}$ Od tada će ova oblast biti predmet konfrontacije ali i spoja Ugarske i Srbije. Srpsko stanovništvo je preko nje znatno lakše migriralo ka severu. ${ }^{11}$ Rezultati tog procesa koji se ne može pratiti postali su vidljivi početkom XV veka kada su ne samo Mačvanska banovina već i susedna oblast Srema i čak jedan deo Bačke uz Dunav bili pretežno naseljeni srpskim stanovništvom. ${ }^{12}$ Vremenom je intenzitet srpsko-ugarskih veza rastao da bi posle 1403. despot Stefan Lazarević pritisnut od Osmanlija prihvatio vazalne obaveze prema kruni Svetog Stefana i tadašnjem ugarskom kralju Žigmundu Luksemburškom. ${ }^{13}$ Brojni posedi koje je Stefan dobio u Ugarskoj, među kojima su pored Mačvanske banovine i Beograda bila i znatna imanja na severoistoku zemlje, pospešila su kretanja srpskog stanovništva ka Ugarskoj već pritisnutog nestabilnošću koju je izazivao turski pritisak sa juga. ${ }^{14}$

Smrt kralja Ugarske Žigmunda Luksemburškog (kralj Ugarske 1387-1437) bila je prelomni trenutak kako za Srbe tako i za Habzburgovce. Srbi su bez podrške Ugarske ubrzo izgubili svoju prestonicu i državu (prvi put 1439. a zatim konačno 1459. godine). Zadatak da brani južne ugarske granice Erdelj i Srpsku despotovinu dobio je novi tek

\footnotetext{
${ }^{9}$ Михајло Динић, Област краља Драгутина после Дежева, Глас, 203, 1951, 61-82; М. Динић, Однос краља Милутина и Драгутина, Зборник радова Византолошког института, 3, 1955.

${ }_{10}$ Споменици за средновековната и поновата историја на Македонија, II, Скопје 1977, 458-488. Objavljeno u teško pristupačnom izdanju Anonymi Descriptio Europae Orientalis, ed. O Górka, Cracoviae 1916; Тибор Живковић, Владета Петровић, Александар Узелац, ANONYMI DESCRIPTIO EUROPAE ORIENTALIS, AНОНИМОВ ОПИС ИСТОЧНЕ ЕВРОПЕ, превод Драгана Кунчер, Београд 2013.

${ }^{11}$ Историја српског народа, књ. II, 314-318.

12 Ј. Шидак, Херетички покрети и одјек хуситизма на словенском југу, Зборник Матице српске за друштвене науке, 31, 1962, 5-23; Dokument je objavljen kod E. Fermendžin, Acta Bosnae potissimum ecclesiastica cum insertis editorum documentorum regestis ab anno 925 usque ad annum 1752, Zagrabiae 1892, $159,162-164$.

${ }^{13} \mathrm{O}$ istoriji srednjovekovne Mađarske (odnosno Ugarske, kako je njen uobičajeni naziv u južnoslovenskoj istoriografiji o srednjem veku) vid. П. Рокаи, 3. Ђере, Т. Пал, А. Касаш, Историја Мађара, Београд 2002; К. Nehring, Matthias Corvinus, Kaiser Friedrich III und das Reich, München 1975; Engel Pál, Magyarország története 1301-1526, Budapest 1998 (Társszerzök: Kristó Gyula, Kubinyi András); Engel Pál, Szent István birodalma. A középkori Magyarország története, Budapest 2001 = Engel Pál, The Realm of St Stephen, A History of Medieval Hungary, 895-1526, New York 2001, 2005²; Perjes Geza, Fall of the Medieval Kingdom of Hungary, New York 1989, o periodu posle 1526. godine Pach Zsigmond Pál, Magyarország története 15261686, Magyarország története tiz kötetban, III/1-2, Budapest 1987; Mikesch Hans, Ungarn zwischen Kreuz und Halbmond, Monch (Bernard \& Graefe Verlag GmbH \& Co. KG); Barta János, Habsburgokés Magyarország a XVI-XVIII században, Debrecen 1997; a o kontaktima Srba sa ovom državom vid. А. Ивић, Историја Срба у Војводини од најстаријих времена до оснивана потиско-поморишке границе (1703), Нови Сад 1929, $1997^{2}$; Ј. Калић, Срби у позном средњем веку, Београд 1994, 2002²; Д. Поповић (ур.), Војводина, I-II, Нови Сад 1940-1941, 2008²; Д. Поповић, Срби у Војводини, I-III, Нови Сад 1957-1963; 1990²; М. Спремић, Деспот Ђурађ Бранковић и његово доба, Београд 1994, 1999²; М. Спремић, Прекинут успон. Српске земље у позном средњем веку, Београд 2005; D. Dinić Knežević, Sremski Brankovići, Istraživanja, 4, 1975; Zombori István (ur.), A szerbek Magyarországon, Szeged 1991.

${ }^{14}$ O Stefanu Lazareviću nema kompletne monografije najznačajniji rad je: А. Веселиновић, Држава српских десnота, Београд 1995. Rad M. Purkovića: Кнез и десnот Стефан Лазаревић, Београд 1978, delimično је zastareo.
} 
izabrani ugarski kralj i prvi Habzburgovac koji je nosio krunu Svetog Stefana. Prvi susret Srba i najpoznatije evropske dinastije bio je tragičan i za jedne i za druge.

Prvi Habzburgovac je na presto Ugarske došao načinom koji će postati karakterističan za ovu dinastiju u narednim vekovima

Bella gerant alii, tu felix Austria nube.

Nam quae Mars aliis, dat tibi diva Venus.

Albert Austrijski je do krune Svetog Stefana došao ženidbom. Naime, bio je oženjen Elizabetom, ćerkom rimsko-nemačkog cara i ugarskog kralja Žigmunda Luksemburškog. Njegova supruga je bila povezana sa brojnim značajnim dinastijama sa jugoistoka Evrope a preko Kotromanića i sa najznačajnijom srpskom dinastijom Nemanjića, što je na neki način simbolično nagoveštavalo budući pravac širenja uticaja i moći ove dinastije. ${ }^{15}$

Mada je na vlast došao ženidbom, prvog Habzburgovca na ugarskom prestolu sačekali su ogromni vojni problemi. Odmah je pristupio važnim zadacima a najvažnije je bilo odbraniti južnu granicu koja je bila izložena snažnom turskom pritisku. Osmanlije su većinu napada usmerili na južne ugarske vazale Srbe. Njihova nova prestonica Smederevo, podignuta desetak godina ranije pošto su Ugarskoj morali vratiti Beograd, bila je kao i cela država pod stalnom opsadom. Turska vojska se pod Smederevom pojavila u kasno proleće 1439. godine. Despot Đurađ Branković je prešao u Ugarsku pokušavajući da obezbedi pomoć. Kralj Albert je upravo tada privremeno rešivši zaplete oko češke krune sa kraljem Kazimirom IV stigao iz Požuna (Bratislave) u Budim. Već tada su građeni brodovi u Beču, Budimu i Beogradu. Trebalo je doturiti žito u Smederevo i poraziti tursku flotu na Dunavu. Despot Đurađ je tokom juna bio sa novim kraljem u Budimu. Sastali su se ponovo 1. avgusta u Segedinu kada je kralj despotu poklonio zamak Vilagoš u Zarandskoj županiji. Đurađ je bio spreman da materijalno pomogne kraljeve napore za prikupljanje vojske koja bi odbranila Smederevo. ${ }^{16}$ Bez obzira na Albertove dobre namere i podsticaje despota Đurđa prikupljanje vojske se sporo odvijalo. Vojska od oko dvadeset i četiri hiljade ljudi pokrenula se ka jugu ali je bila slabo snabdevena hranom. Uz novčanu pomoć despota Đurđa vojska je stigla do ušća Tise u Dunav. Nemajući snage za ozbiljnije aktivnosti, ovde se zadržala sačekavši pad Smedereva a potom se postepeno i razišla. Kralj Albert je ostavši sa malo ljudi lutao na prostoru između Slankamena, Titela, Petrovaradina i Futoga. Tokom tih lutanja kralj je, kao i značajan deo vojske, oboleo od dizenterije. Na putu za Beč umro je u mestu Nesmelju na granici današnje Mađarske i Slovačke, 27. oktobra 1439. godine. Smederevo se u međuvremenu predalo Turcima, posle tromesečne opsade, najverovatnije zbog gladi. ${ }^{17}$ Najstariji Đurđev sin Grgur i šurak Toma Kantakuzin su ovu odluku doneli svesni da je dalja odbrana nemoguća te da uprkos činjenici da Turci nisu postigli vojni uspeh grad sigurno pada. Zato

\footnotetext{
${ }^{15}$ Günther Hödl, Albrecht II., Königtum, Reichsregierung u Reichsreform 1438-1439, Wien-Köln-Graz 1978.

${ }^{16}$ Иван Божић, Две белешке о Филипу де Диверсису, Зборник Филозофског факултета 11-1, 1970, 319-324.

${ }^{17} \mathrm{O}$ datumu pada postoje protivrečni podaci. U najvećem delu literature prihvata se 18 . avgust, ali u delu novije literature prihvata se 27. avgust 1439 .
} 
su predajom želeli da izbegnu pustošenje Smedereva. ${ }^{18}$

Tako se nesrećno i po Srbe i po Habzburgovce završio njihov prvi susret $u$ kraljevstvu Svetog Stefana. Jedan Habzburgovac je izgubio život pokušavajući odbraniti prestonicu Srpske despotovine a Srbi su prvi put ostali bez države, što će postati konstanta tokom naredna četiri veka.

Jedini sin Albrehta II i Elizabete Luksemburške rodio se četiri mesece posle kraljeve smrti u Komaromu, u današnjoj Slovačkoj. Bio je poznat kao Ladislav Posthumus (Posmrče). ${ }^{19}$ Krunisan je kao vladar Ugarske ubrzo po rođenju. Ugarski sabor je u međuvremenu izabrao za kralja poljskog vladara Vladislava Jagelonca. Vojne akcije koje je Ugarska preduzela u narednim godinama, mada su završene njenim teškim porazima, omogućile su despotu Đurđu da privremeno obnovi državu. ${ }^{20}$ Za ovaj period je vezana i jedna od prvih seoba Srba na sever Ugarske. Prilikom opsade Smedereva stradao je obližnji Kovin. Deo stanovnika je odlučio da se sa ovog izloženog mesta preseli negde na sever. Novo naselje su osnovali na velikom dunavskom ostrvu Čepelu, nešto južnije od Budima. Ubrzo im je novi kralj Vladislav I potvrdio povlastice i dodelio zemljište. ${ }^{21}$

Mada je predvođena gubernatorom Jankom Hunjadijem Ugarska stabilizovala granicu sa Turcima povremeno vodeći i ofanzivne akcije, nije bila u stanju da išta učini dok su balkanske zemlje padale u turske ruke. Pošto je 1453. zauzeo Konstantinopolj, mladi turski sultan Mehmed II se tri godine kasnije pojavio pred Beogradom. Uz krajnje napore Janko Hunjadi je uz podršku franjevca Jovana Kapistrana uspeo da odbrani grad, ali je neposredno posle toga umro od posledica kuge. ${ }^{22}$

Za trenutak se u blizini Despotovine u Beogradu pojavio sledeći Habzburgovac, Ladislav Posmrče. On je zajedno sa svojim starateljem Ulrihom Celjskim i manjim odredom vojske stigao pod Beograd posle povlačenja Turaka. U Beogradu je Ulriha Celjskog ubio Ladislav Korvin. Tri meseca kasnije Ladislav V Posmrče je u Budimu zbog ovog događaja osudio Ladislava Korvina na smrt. Ovaj Habzburgovac nije ostavio neki drugi trag u Ugarskoj. Umro je u Pragu 23. novembra 1457. ne dočekavši ni punu godinu realne vladavine. Za ugarskog vladara je 10. decembra 1440. izabran mlađi sin Janka Hunjadija, Matija Korvin.

I dok su Habzburgovce privremeno iz Ugarske istisnuli domaća dinastija Hunjadijevaca a kasnije i poljski Jagelonci, Srbi su u sve većem broju pristizali u Ugarsku. Konačni pad središta Srpske despotovine Smedereva (1459) je bio jedan od ključnih trenutaka. Mada je Srba u Ugarskoj bilo u značajnijem broju već u periodu posle Kosovske bitke, tokom druge polovine XV veka njihov broj se u južnim delovima

\footnotetext{
${ }^{18}$ Detaljno o prvoj opsadi Smedereva vid.: М. Спремић, Деспот Бурађ Бранковић и његово доба, Београд, 1999, 244-252.

${ }^{19}$ Gertrud Buttlar, Die Belagerung des Ladislaus Postumus in Wiener Neustadt 1452, Wien 1986.

${ }^{20}$ М. Спремић, Деспот Ђурађ Бранковић и његово доба, 318-356. Za noviju literaturu vid. Imber Colin, The Crusade of Varna, 1443-45, Aldershot - Burlington 2006. i John Jeffferson, The holy wars of King Wladislas and Sultan Murad: the Ottoman-Christian conflict from 1438-1444, Leiden - Boston 2012.

${ }^{21}$ Ime Kovin prenelo se i na novo naselje koje je nazvano Gornji ili Mali Kovin a kasnije i Srpski Kovin (Ráczkeve). Kovinske privilegije su objavljene u jednoj danas retkoj publikaciji: István Magdics, Diplomatarium Ráczkeviense, Székesfejérvár 1888. O sličnoj seobi Srba na sever vid.: С. Ћирковић, Rasciani regales Владислава I Јагелонца, Зборник Матице српске за историју, 1, 1970, 79-82.

22 Јованка Калић-Мијушковић, Београд у средњем веку, Београд 1967.
} 
Ugarske značajno uvećavao. Tome su doprinele i ratne aktivnosti Matije Korvina u koje su uvučeni ne samo brojni srpski feudalci nego i velik deo srpskog etnosa. Brojni vojni pohodi sa obe strane menjali su etničku sliku oblasti uz Savu i Dunav. ${ }^{23}$ Koliki je bio nivo pustošenja na granici najbolje vidimo iz jednog pisma kralja Matije upućenog Veneciji 1462. godine u kome se žalio da su Turci u prethodne tri godine iz njegove kraljevine odveli 200.000 stanovnika. $^{24}$ Nešto kasnije se situacija promenila, odbrana ugarske granice je učvršćena a veliki broj Srba se doselio u Srem. Vojska kralja Matije je dovodila mnoštvo ljudi iz Smederevskog sandžaka i drugih oblasti Turske. Naročito velika preseljenja stanovništva su izvršena 1480. i 1481. godine kada je na ugarsku teritoriju preseljeno više od 100.000 ljudi. Ne može se utvrditi gde su se ovi preseljenici tačno smestili. Na velikom prostoru koji je bio na pravcu migracija Srbi su se verovatno selili uz Tisu na sever a zatim duž Moriša i Kriša na istok. Pojedina naselja su formirana i u Erdelju. Nastale su i dve zone sa zgusnutim srpskim življem: jedna neposredno uz granicu uz Dunav a druga u području reke Moriš. Prva zona je bila vezana uz granicu a na formiranje druge su mogla uticati imanja koja su ovde imali srpski vlastelini Jakšići i Belmuževići. Veoma velik broj Srba živeo je i u Sremu. ${ }^{25}$

U ugarsku kraljevinu je pored stanovništva prelazio i jedan deo srpskog plemstva. Većina nije ostavila neki značajan trag. Tako su u Sremu kao srpski vlastelini u službi kralja Matije boravili Grgur Popović i porodica Potrečić. Među srpskim feudalcima koji su prešli na teritoriju Ugarske daleko najznačajniji bili su potomci tada najuglednije srpske porodice Branković. Prvo je u Matijinu službu prešao vanbračni sin despota Grgura Brankovića, Vuk Grgurević, krajem 1464. ili početkom 1465. godine. Bio je to sasvim nov kvalitet u srpskom elementu u Ugarskoj. Ugled, državna i porodična tradicija porodice Branković bili su izuzetni, i to ne samo među Srbima. Vuk Grgurević je nekoliko godina po padu Smedereva bio u službi Osmanlija, a po prelasku na ugarsku stranu je dobio neka imanja u Sremu u koja su ulazila mesta Kupinik, Irig i Berkasovo. Svojim ratničkim podvizima stekao je izuzetan ugled u čitavoj Ugarskoj a istovremeno je značajno ojačavao pozicije ugarskog kralja među Srbima sa obe strane granice, što je u tom trenutku bilo od strateškog značaja. Zato nije čudno što je Matija Korvin posle njegove smrti (16. april 1485) uložio napore da mu nađe naslednike. Otkrio ih je u liku njegove braće od strica Đorđa i Jovana. Oni su posle mnogih lutanja sa svojim ocem Stefanom, koji je umro 1477. godine u Italiji, boravili pod pokroviteljstvom cara Fridriha III u zamku Vajtersfeld u Štajerskoj. Njihov dolazak u Srem u februaru 1486. bio je od izuzetnog značaja. Bez obzira na njihov dotadašnji boravak van srpskog etničkog prostora nosili su izuzetno snažnu svest o svom poreklu i tradiciji. To se vidi ne samo iz činjenice da su sa sobom doneli mošti svog oca kao najveću dragocenost već i po uspostavljanju kulta vladara po ktitorstvu i zaštiti nad manastirima u Svetoj gori i konačno po monašenju starijeg brata Đorđa i prihvatanju crkvenog dostojanstva. Pored toga što su dobili deo imanja Vuka

\footnotetext{
${ }^{23}$ Историја српског народа, II, 431-444.

${ }^{24}$ Mada brojke iz srednjovekovnih dokumenata moramo uzimati sa rezervom, možemo iz njih zaključiti o velikom obimu razaranja i demografskog pustošenja: I. Nagy - A. Nyáry, Magyar diplomacziai emlékek, I, Budapest 1877, 112.

${ }^{25}$ Историја српског народа, II, 431-444.
} 
Grgurevića, oba brata će nositi despotsku titulu svojih predaka. ${ }^{26}$

Veliki ugled stekli su i predstavnici feudalnih porodica Jakšić i Belmužević. Porodica Jakšić se preselila u Ugarsku 1464. Predvodili su je dva brata: Stefan i Dmitar. Najverovatnije je da su bili sinovi istaknutog službenika despota Đurđa Brankovića, Jakše Breščića. Jakša se pominje kao zapovednik despotovog odreda od 1.500 ljudi koji je 1453. učestvovao u opsadi Konstantinopolja. Braća Jakšići su prešli u Ugarsku u drugoj polovini 1464. godine kada im je kralj Matija dodelio vlastelinstvo u Čanadskoj županiji sa gradom Nađlakom. Do tada su svakako bili u turskoj službi i pripadali onom delu vlastele koji je bio naklonjen Turcima i podržavao njihovo zauzeće Smedereva a zauzvrat uspeo da sačuva posede. Porodica je vremenom unapredila svoje pozicije. Stefan i Dmitar su imali mnogobrojno potomstvo. Stefanov sin Stefan oženio se Milicom, ćerkom Miloša Belmuževića, te još više uvećao imanja Jakšića. ${ }^{27}$

Uz porodicu Jakšić najznačajniji srpski vlastelin sa posedima na ovom području bio je Miloš Belmužević. Nismo sigurni kada se on preselio u Ugarsku, mada je već osamdesetih godina imao u svojim rukama znatna imanja. Pošto mu je sin jedinac poginuo u borbi sa Turcima, većinu imanja je kasnije nasledila njegova ćerka Milica, koja ih je odnela u miraz Stefanu Jakšiću. ${ }^{28}$

U ovom periodu Matija Korvin je značajno ojačao svoje vojne snage. Među lakim konjanicima husarima Srbi su činili značajan deo. Veruje se da su banderije despota, Jakšića i Belmuževića u kojima je služio veliki broj Srba imale oko 2.000 ljudi. Oni su činili značajan deo i među 5.000 vojnika koji su neprekidno boravili u tvrđavama na granici. Svi ovi srpski feudalci su raspolagali velikim vojnim snagama koje su uglavnom plaćane uz podršku ugarskog kralja. Jedan izvor čak navodi da su laki konjanici bili ratnici „iz Raške ili Srbije“ i odlikovali su se velikom pokretljivošću te su za jednu noć mogli da

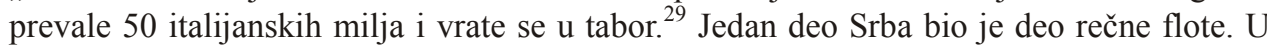
periodu kralja Matije nasadi, mali brodovi, na kojima su dobrim delom služili Srbi, činili su desetinu flote, a u narednim decenijama njihov broj se značajno povećavao. ${ }^{30}$

\footnotetext{
26 Temeljni rad o istoriji Sremskih Brankovića objavila je Dušanka Dinić Knežević, Sremski Brankovići, Istraživanja, 4, 1975, 5-47. O Vuku Grgureviću vid.: С. Ћирковић, О деспоту Вуку Гргуревићу, Зборник за ликовну уметност Матице српске, 6, 1970, 283-290, takođe i: Историја српског народа, II, 373-389, 445-464.

${ }^{27}$ M. Lendvai, Temes vármegye nemes családai, I, Budapest 1896, 60. С. Станојевић, Нешто о Јакшићима, Нова искра, 3, 1901, 3-9; Ј. Радонић, Прилози за историју браће Јакиића, Споменик, 59, 1923, 61-76; Samu Borovszky, A nagylaki uradalom története, Értekezések a történeti tudományok körébol, 18, 1900, 17. Po Borovskom, Jakšići su zagospodarili Nađlakom između 9. avgusta 1464. i januara 1465. jer se 10. avgusta raspravljalo o jednom sporu u Čanadskoj županiji u kome su i oni učestvovali.

${ }_{28}$ O Belmuževićima vid.: К. Јиречек, Историја Срба, I, 375-376, 381-407; II, 390-391, Београд 1978; И. Божић, Немирно Поморје, Београд 1979, 188, 191. Testament je objavljen u: A. Ivić, Nekoliko ćirilskih spomenika XVI i XVII veka, Vjesnik Zemaljskog arhiva, 15, 1913, 93-94. O nekim nedoumicama vezanim za sporna pitanja iz istorije porodice vid.: N. Lemajić, O nekim nejasnim pitanjima iz istorije porodice Belmužević, Međunarodni naučni skup „Balkan i Panonija kroz istoriju“, Novi Sad - Sremska Mitrovica 2005, kaо i: Ненад Лемајић, Српска елита на прелому епоха, Сремска Митровица - Источно Сарајево 2006, 195-206.

${ }^{29}$ Историја српског народа, II, 436-437; L. Ovary, Mátyás király szárazföldi vizi haderejének leirasa az 1479ki hadjáratból, Történelmi tár, 1885, 762-764; Ненад Лемајић, Српска елита на прелому епоха, Сремска Митровица - Источно Сарајево 2006.

${ }^{30}$ Szentkláray Jenö, A dunai hajóhadak története, Budapes, 1885; Гаврило Витковић, Прошлост, установе споменици угарских краљьевих шајкаша, Гласник СУД, 1887; Сима Ћирковић, Почеци шајкаша, Пловидба на Дунаву и юеговим притокама кроз векове, Београд 1983.
} 
Pored ratova sa Turcima kralj Matija Korvin je ratovao i sa Habzburgovcima $u$ Austriji, zauzevši u jednom trenutku i Beč. Ostalo je zabeleženo da su u ovim ratovima posebno uspešni i surovi bili srpski ratnici u službi kralja Matije. Strah koji su svojim izgledom i načinom ratovanja izazvali zapamćen je među podanicima Habzburgovaca u Austriji i Štajerskoj. ${ }^{31}$

Vremenom su odnosi Ugarske i Habzburgovaca, koji su posle sloma Celjskih postali najsnažnija vojna i politička sila oblasti, postajali sve isprepletaniji. Bračne veze između ugarskih vladara iz dinastije i Habzburgovaca bivale su sve češće.

Kada je posle iznenadne smrti kralja Matije 1490. godine došlo do borbe za presto između nekoliko pretendenata, Habzburgovci su se pozivali na ugovor koji je Matija potpisao sa Fridrihom III u Bečkom Novom Mestu 1463. a po čijim odredbama su u Ugarsku vraćeni kruna Svetog Stefana i neki gradovi na zapadu zemlje a u kome je postojala klauzula o međusobnom nasleđivanju. Pretendenti su bili i sinovi poljskog kralja Kazimira: Vladislav, u to vreme već češki kralj, i Jan Olbraht, kao i Ivaniš Korvin, vanbračni sin Matije Korvina iz veze sa jednom šleskom plemkinjom. Poslednji se u borbe uključio i rimsko-nemački kralj Maksimilijan Habzburg. ${ }^{32}$ Sinovi poljskog kralja su rodbinski po majčinskoj liniji bili povezani sa granom Habzburga kojoj su pripadali Albert i Ladislav Posmrče tako da su i njihova prava posredno proisticala iz naslednih prava habzburške dinastije, ali su ih oni pre svega izvodili kao potomci Žigmunda Luksemburškog. Kada je Maksimilijan oktobra 1490. počeo vojne akcije u Ugarskoj pokušavajući da ostvari prava koja su poticala iz ugovora kralja Matije i cara Fridriha, njemu su pristupili i najznačajniji srpski feudalci u Ugarskoj: despot Đorđe Branković i njegov brat Jovan. Oni su sa jednom grupom značajnih ugarskih feudalaca 1. novembra 1490. godine izdali povelju kojom su za ugarskog kralja priznali Maksimilijana. Habzburgovci ipak nisu uspeli ni ovaj put da se dokopaju krune Svetog Stefana. Nemajući dovoljno snaga da se održi u Ugarskoj, Maksimilijan je morao sklopiti ugovor kojim je prihvatio Vladislava Jagelonca za kralja uz uslov da se obnove odrednice ugovora iz 1462. godine, odnosno da Habzburgovci naslede krunu ukoliko novi ugarski kralj umre bez zakonitih naslednika. Ugarski sabor se nećkao, ali se na kraju 7. marta 1492. godine saglasio sa njegovim uslovima i izdao povelju. Među potpisnicima povelje se pominje i despot Đorđe (Georgius regni Rascie despotus). ${ }^{33}$ Veoma uporno Habzburgovci su pripremali svoj dolazak na presto Ugarske. Sledeći korak su načinili 1506. kada su car

\footnotetext{
${ }^{31}$ Милица Кисић, Antonius Bonfinius, Rerum Ungaricarum decades, decas IV: превод са коментарима и филолошко - историјска анализа, neobjavljena doktorska disertacija

32 O Maksimilijanu detaljnije vid. H. Wiesflecker, Österreich im Zeitalter Maximilians I. Die Vereinigung der Länder zum frühmodemen Staat. Der Aufstieg zur Weltmacht, Verlagfür Geschichte und Politik - Oldenbourg, WienMünchen 1999; H. Wiesflecker, Kaiser Maximilian I. Das Reich, Osterreich und Europa an der Wende der Neuzeit, Bd. V. München 1986; L. Silver, L, Shining Armor: Maximilian I as Holy Roman Emperor, Art Institute of Chicago Museum Studies, Vol. 12, No. 1, Chicago, Autumn 1985, 8-29; L. Silver, Caesar Ludens: Emperor Maximilian $I$ and the Waning Middle Ages, u: Cultural Visions: Essays in the History of Culture (eds. Penny Schine Gold and Benjamin C. Sax), Internationale Forschungen zur Allgemeinen und Vergleichenden Literaturwissenschaft, Bd. 41, Rodopi, Amsterdam 2000, 173-196; L. Silver, Marketing Maximilian - The Visual Ideology of a Holy Roman Emperor, Princeton and Oxford 2008.

33 O učešću srpskih velikaša u ovim zapletima vid.: Снежана Божанић, Српски великаши у политичким и војним превирањима око избора Владислава II за краља Угарске, Истраживања, 24, Нови Сад 2013, 151-166.
} 
Maksimilijan i Vladislav II potpisali sporazum o međusobnom nasleđivanju. Ovaj potez je bio uslovljen odlukom Ugarskog sabora iz 1505. Tada je već ojačalo ugarsko plemstvo na predlog velikog pravnika i kasnijeg ugarskog palatina Stefana Verbecija donelo odluku da stranac ne može biti biran za kralja Ugarske. Maksimilijan je vojnim pritiskom i ulaskom u Ugarsku pokušao da ojača svoje pozicije i prisili plemstvo na povlačenje odluke, ali nije postigao uspeh. Pitanje je privremeno izgubilo na značaju kada se Vladislavu rodio sin. Prethodni ugovori o nasleđivanju biće ponovo potvrđeni na kongresu u Beču 1515. kada je ugovoreno dvostruko venčanje: ugarskog kralja Lajoša II i Maksimilijanove unuke Marije, kao i Maksimilijanovog unuka Ferdinanda (odnosno privremeno samog Maksimilijana) i sestre kralja Lajoša II Ane. Posle ovih dinastičkih i političkih priprema Habzburgovci su postali još bliži prestolu Svetog Stefana bez obzira na zaključak Ugarskog sabora iz $1505 .{ }^{34}$ Završni koraci u utvrđivanju habzburuškog legitimiteta nasleđivanja krune Svetog Stefana učinjeni su 21. maja 1521. kada su se u Lincu venčali Ferdinad i Ana a potom je 13. januara 1522. u Budimu obavljeno venčanje Lajoša II i Ferdinandove sestre Marije.

Mladi ugarski kralj Lajoš II bio je tek desetogodišnjak kada je preuzeo presto. Kraljevinom je vladalo kolektivno regentstvo od dvadeset osam članova. Jaz među različitim društvenim grupama pogotovo od Dožinog ustanka se povećavao, a vojni sistem iz vremena kralja Matije je dobrim delom ruiniran. Među domaćim plemstvom posebno se isticao pobednik nad seljačkom vojskom kuruca Jovan Zapolja, plemić iz Erdelja čija je porodica imala slovensko poreklo. Dolazak na presto novog sultana Sulejmana II (1520) Ugarska nije dočekala spremna za rat i pored zaključaka vezanih za odbranu zemlje donetih na saboru u Baču dve godine ranije. Već sledeće godine Turci su osvojili Beograd i Šabac i najvećim delom uništili odbrambene potencijale u Sremu. Bio je to tek uvod za veliki pohod 1526. godine. Podeljena ugarska aristokratija nije bila u stanju da objedini svoje već ograničene vojne potencijale. Turskoj vojsci koja je brojala oko 100.000 vojnika suprotstavila se ugarska vojska od oko 25.000 vojnika predvođenih Lajošem II. Bitka je odlučena u svega dva sata strahovitim porazom hrišćana. Pored kralja u bici su izgubili život i brojne ugledne ličnosti države i crkve.

Dok su Habzburgovci složenim sistemom diplomatskog, političkog i vojnog pritiska kao i bračnim ugovorima ojačavali svoja prava na Ugarsku, Srbi su dalje povećavali svoje etničko prisustvo posebno u južnim krajevima ove zemlje. Zapovednik južne granice kaločko-bački nadbiskup Pavle Tomori pokušao je iskoristiti potencijale Srba u odbrani zemlje. Na svoju stranu je privukao i jednog od najuglednijih Srba u Smederevskom sandžaku Pavla Bakića, koji je nekoliko meseci pred Mohačku bitku prešao u Ugarsku sa porodicom, petoro braće i pedeset vojnika. ${ }^{35}$ Pored Pavla Bakića veliki ugled je imao i Radič Božić, ugledni Srbin iz Pomorišja i jedan od komandanata nasadista Petar Ovčarević. ${ }^{36}$ Pavle Tomori je računao da uz pomoć Srba ojača odbranu

\footnotetext{
${ }^{34}$ П. Рокаи, 3. Ђере, Т. Пал, А. Касаш, Историја Мађара, 176-178.

${ }^{35}$ Nenad Lemajić, Bakići porodica poslednjeg srpskog despota, Novi Sad 1995, 1-155; Ненад Лемајић, Српска елита на прелому епоха, Сремска Митровица - Источно Сарајево 2006; Ненад Лемајић, Донационе повеље породице Бакић, Истраживања, 16, 2005, 153-169.

${ }^{36} \mathrm{O}$ ovim ličnostima ne postoji poseban rad. Najdetaljnije je o njima pisao А. Ивић, Историја Срба у Војводини.
} 
granice u Sremu za koju se zbog nedostatka novca nisu mogli obezbediti vojnici. U jednom pismu koje je uputio neposredno pred bitku na Mohaču Tomori navodi da su mogli imati besplatno dvadeset hiljada ljudi za odbranu samo da je vojska na vreme poslana, kako je ranije zahtevano. ${ }^{37}$ Pošto pomoć do prelaska Turaka u Srem nije stigla, sremski Srbi su otišli u krajeve oko Moriša gde će kasnije učestvovati u pokretu Jovana Nenada. ${ }^{38}$

Turci su veoma ozbiljno spremali pohod koji je doveo do Mohačke bitke. Vojska je iz Carigrada krenula 23. aprila 1526. Ugarska vojska se počela prikupljati tek kada su turske prethodnice stigle do Save. Turci su zauzeli Petrovaradin a 14. avgusta su izbili pred Osijek koji se predao gotovo bez borbe.

Osnovna strateška zamisao Ugara bila je da spreče prelazak Turaka preko Drave. Usput su se kraljevoj vojsci pridružili odredi nekih velikaša. Tu se našao i Pavle Bakić, koji je u pograničnoj Tomorijevoj vojsci zauzimao ugledan položaj. Pošto se prelaz preko Drave nije mogao braniti, bilo je očigledno da će se morati prihvatiti bitka. Kako navodi čuveni istoričar Ištvanfi, na savetovanju ugarskih predvodnika koje je tim povodom održano, uzeli su učešće Radič Božić, zapovednik nasadista, i Pavle Bakić. Njih dvojica su podržali predlog Leonarda Gnojenskog da se načini utvrđenje od kola koja bi se povezala lancima i tako dočeka nadmoćniji neprijatelj. Predlog nije bio prihvaćen, jer je isuviše odstupao od uobičajenog načina ratovanja ugarske feudalne vojske. Sudar vojski odigrao se 29. avgusta 1526. godine i vrlo brzo bitka je bila rešena. Kao i u mnogim bitkama do tada, Ugri su pokušali da snažnim prodorima oklopljenih konjanika nadoknade ogromnu brojčanu premoć neprijatelja. Očekujući upravo takvu taktiku ugarske vojske, sultan joj se suprotstavio uređenim dejstvom artiljerije i uvežbanom pešadijom. Razbivši bojni red oklopnika, Turci su lako rešili bitku. Celokupna ugarska pešadija i najveći deo oklopnika su stradali, dok je laka konjica uglavnom uspela da izbegne uništenje. O učešću srpskih ratnika u samoj bici nema previše podataka, znamo da je u njoj poginuo jedan brat Pavla Bakića. ${ }^{39}$

Posle mohačke katastrofe Ferdinad I će pretendovati na ugarsku krunu. Ove pretenzije će i ostvariti porazivši Jovana Zapolju u bitkama kod Tokaja i Sine. Time će otpočeti nov period veoma intenzivnih kontakata Srba sa Habzburgovcima koji će se najvećim delom odvijati na teritoriji razdrobljenog ugarskog kraljevstva koje se borilo za svoj opstanak.

\footnotetext{
${ }^{37}$ V. Fraknói, Tomori Pál kiadatlan levelei, Történelmi Tár, 1882, 94.

${ }^{38}$ Isto, 94. „Tota etiam rascianitas hinc de portu abiit, ad aliam partem Morosii, quia Maiestas vestra non curauit quando scribebam; quod si Maiestas Vestra in tempore gentes huc demittere dignaretur, vel viginti mille homines possemus hic in portu gratis conservare, ex colonis; sed jam quando nom habuerunt in quo sperarent, omnes abierunt." Da su Srbi iz Srema činili jezgro vojske Jovana Nenada smatra i F. Szakály, Remarques sur l armée de Jovan Tcherni, Acta Historica, Academiae Scientiarum Hungaricae, 24, 1978, 76. „Les réfugiés de la Sirmie, qui formaient la base de l'armée de Iovan, étaient jusque - lá liés á la Hongrie de Mathias et des Jagellon, pour avoir trouvé en territoire hongrois une nou velle patrie et une ex is tence“.

${ }^{39}$ O samoj bici vid.: L. Bende, A mohacsi csata, Hadtörténelmi Közlemények, 1966, 532-564; I. Brodarics, Historiaja a mohacsi veszrol, I Szentpetery, 1908 (repr. 1975); B. Kis, II. Lajos halala, Vigilia, 41, 1976, 507-512; G. Perjes, A mohacsi csata, Hadtörténelmi Közlemények NS, 23, 1976; G. Perjes, Mohacs, 1979; Geza Perjes, The fall of medieval kingdom of Hungary: Mohacs 1526 - Buda 1541, Columbia University Press 1989; F. Szakály, A mohacsi csata, 1975; S. Brodarić, Mohačka bitka 1526, prev. S. Sršan, Vinkovci 1990.
} 
Izvori i literatura:

Borovszky, Samu, A nagylaki uradalom története, Értekezések a történeti tudományok körébol, 18, 1900 .

Божанић, Снежана, Српски великаши у политичким и војним превирањима око избора Владислава II за краља Угарске, Истраживања, 24, 2013.

Божић, Иван, Немирно Поморје, Београд 1979.

Божић, Иван, Две белешке о Филипу де Диверсису, Зборник Филозофског факултета, 11-1, 1970, 319-324.

Brodarić, Stjepan, Mohačka bitka 1526, prev. S. Sršan, Vinkovci 1990.

Веселиновић, Андрија, Држава српских деспота, Београд 1995.

Витковић, Гаврило, Прошлост, установе и споменици угарских краљевих шајкаша, Гласник СУД, 1887.

Górka, Olgierd, Anonymi descriptio Europae Orientalis „Imperium Constantinopolitanum, Albania, Serbia, Bulgaria, Ruthenia, Ungaria, Polonia, Bohemia" anno MCCCVIII exarata ed., praef. et adnotationibus instruxit Olgierd Górka, Cracoviae 1916.

Dinić Knežević, Dušanka, Sremski Brankovići, Istraživanja, 4, 1975.

Динић, Михајло, О угарском ропству краља Уроша I, Историјски часопис, 1, 1948.

Динић, Михајло, Област краља Драгутина после Дежева, Глас, 203, 1951.

Динић, Михајло, Однос краља Милутина и Драгутин, Зборник радова Византолошког института, 3, 1955.

Живковић, Тибор - Петровић, Владета - Узелац, Александар, ANONYMI DESCRIPTIO EUROPAE ORIENTALIS, AHOНИМOВ ОПИС ИСТОЧНЕ ЕВРОПЕ, превод Драгана Кунчер, Београд 2013.

Zombori, István (ur.), A szerbek Magyarországon, Szeged 1991.

Ивић, Алекса, Историја Срба у Војводини од најстаријих времена до осниваға потископоморишке гранище (1703), Novi Sad 1929, $1997^{2}$.

Ivića, Aleksa, Nekoliko ćirilskih spomenika XVI i XVII veka, Vjesnik Zemaljskog arhiva, 15, 1913.

Историја сриског народа, I-II, Београд 1981-1982.

Калић-Мијушковић, Јованка, Београд у средњем веку, Београд 1967.

Калић, Јованка, Рашки велики жупан Урош II, Зборник радова Византолошког института, 12, 1970.

Калић, Јованка, Европа и Срби, средњи век, Београд 2006.

Калић, Јованка, Жупан Белош, Зборник радова Византолошког института, 36, 1997.

Калић, Јованка, Срби у позном средњем веку, Београд 1994, $2002^{2}$.

Кисић, Милица, Antonius Bonfinius, Rerum Ungaricarum decades, decas IV: nревод ca коментарима и филолошко-историјска анализа, необјављена докторска дисертација.

Лемајић, Ненад, Донационе повеље породице Бакић, Истраживања, 16, 2005.

Лемајић, Ненад, Српска елита на прелому епоха, Сремска Митровица - Источно Сарајево 2006.

Lemajić, Nenad, Bakići, porodica poslednjeg srpskog despota, Novi Sad 1995.

Lemajić, Nenad, O nekim nejasnim pitanjima iz istorije porodice Belmužević, Međunarodni naučni skup „Balkan i Panonija kroz istoriju“, Novi Sad - Sremska Mitrovica 2005.

Lendvai, Miklós, Temes vármegye nemes családai, I, Budapest 1896.

Magdics, István, Diplomatarium Ráczkeviense, Székesfejérvár 1888.

Nagy, Iván-Nyáry, Albert, Magyar diplomacziai emlékek, I, Budapest 1877.

Óváry, Lipót, Mátyás király szárazföldi vizi haderejének leirasa az 1479-ki hadjáratból, Történelmi tár, 1885. 
Поповић, Душан (ур.), Војводина, I-II, Нови Сад 1940-1941, $2008^{2}$.

Поповић, Душан, Срби у Војводини, I-III, Нови Сад 1957-1963, $1990^{2}$.

Пурковић, Миодраг, Кнез и деспот Стефан Лазаревић, Београд 1978.

Радонић, Јован, Прилози за историју браће Јакиића, Споменик, 59, 1923.

Рокаи, Петер - Ђере, Золтан - Пал,Тибор - Касаш, Александар, Историја Мађара, Београд 2002.

Рокаи, Петер, Gyletus dux Sirmii, Зборник Матице српске за историју, 27, 1983.

Рокаи, Петер, О једном наслову Калојана Анђела, Зборник радова Византолошког института, 19, 1980.

Szakály, Ferenc, Remarques sur l armée de Jovan Tcherni, Acta Historica, Academiae Scientiarum Hungaricae, 24, 1978.

Szentkláray, Jenö, A dunai hajóhadak története, Budapest 1885.

Szentpétery, Emerich, Das Banat von Machow (Macsó), Ungarische Rundschau für historische und soziale Wissenschaften, 1915, 4.

Спомениии за средновековната и поновата историја на Македонија, II, Скопје 1977.

Спремић, Момчило, Деспот Бурађ Бранковић и његово доба, Београд 1994, $1999^{2}$.

Спремић, Момчило, Прекинут успон. Српске земье у позном средњем веку, Београд 2005.

Станојевић, Станоје, Нешто о Јакшићима, Нова искра, 3, 1901.

Ћирковић, Сима, Rasciani regales Владислава I Јагелониа, Зборник Матице српске за историју, $1,1970$.

Ћирковић, Сима, Земља Мачва и град Мачва, Прилози за књижевност, језик, историју и фолклор, бр. 1-4, 2008.

Ћирковић, Сима, O деспоту Вуку Гргуревићу, Зборник за ликовну уметност Матице српске, 6 , 1970.

Ћирковић, Сима, Почечи шајкаша, Пловидба на Дунаву и његовим притокама кроз векове, Београд 1983.

Ћирковић, Сима, Срби у средњем веку, Београд 1995.

Ћирковић, Сима, Црна Гора и проблем српско-угарског граничног подручја, у: Ваљево постанак и развој градског средишта, Ваљево 1994.

Fermendžin, Eusebius, Acta Bosnae potissimum ecclesiastica cum insertis editorum documentorum regestis ab anno 925 usque ad annum 1752, Zagrabiae 1892.

Fraknói, Vilmos, Tomori Pál kiadatlan levelei, Történelmi Tár, 1882.

Харди, Ђура, Господари и банови оностраног Срема и Мачве у ХIII веку, Споменица Историјског архива Срем, бр. 8, 2009.

Hödl, Günther, Albrecht II., Königtum, Reichsregierung u Reichsreform 1438-1439. Wien-Köln-Graz 1978.

Шидак, Јарослав, Херетички покрети и одјек хуситизма на словенском југу, Зборник Матице српске за друштвене науке, 31, 1962. 
NENAD LEMAJIĆ

\title{
EARLY CONTACTS BETWEEN THE SERBS AND THE HABSBURGS (TO THE BATTLE OF MOHÁCS)
}

\begin{abstract}
Summary
The contacts between the Serbs and the Habsburgs started around the middle of the $15^{\text {th }}$ century. At that time the Habsburgs in the person of Albert of Austria first ascended the throne, while Serbs were fighting for the survival of their medieval state. Later the character of these contacts became different. Individual Serbian representatives, such as feudal lords who fled to the territory of Hungary and new leaders of warrior bands, made contacts with the Habsburgs offering them their military service. The definite breakthrough happened in the time after the Battle of Mohács, when Ferdinand I Habsburg solidified his position on the throne of Hungary. This marked the beginning of a new period of very intensive contacts between the Serbs and the Habsburgs, which would mainly be made in the territory of the crumbled Hungarian Kingdom fighting for its survival.
\end{abstract}

Keywords: Serbs, Habsburgs, Hungary, Serbs in Hungary. 